\title{
Women on the Row: Revelations from Both Sides of the Bars By Kathleen O'Shea. Ithaca: Firebrand (2000), 156 pp. Reviewed by Karlene Faith
}

Kathleen O'Shea has written a remarkable book based on interviews and They have been convicted of killing police officers, husbands, their own children, and random victims. However, these stories dispel media-driven stereotypes of "dangerous killers," and give a human face to women sentenced to die in the only Western nation whose judiciary still permits the death penalty (thirty-eight states exercise this prerogative). Reading about these women's lives in their own words, and learning the contexts in which their crimes occurred, one can recognize their reasons for snapping and succumbing to rage, acting under coercion, or even intentionally calculating another's demise.

In a vivid illustration of empathy, O'Shea focuses on very personal elements of her own biography. Her themes echo those of the women she interviews, and she alternates her voice with theirs. For example, O'Shea begins a chapter with "I don't ever remember loving Mother and I'm not sure she ever loved me" (p. 45). She then relates the story of Kelley who, at age five, witnessed the death of her mother in a house fire. Kelley herself was severely burned; as a child she suffered over seventy-five skin grafts and constant humiliation over her appearance. O'Shea quotes women's expressions of devotion to their children: "The loves of my life are my children. They are the only true loves I'll ever have" (p. 46). This is juxtaposed against her own story of being adopted from infancy by a relative, but secretly knowing that her older cousin was her mother. These are stories of loss and lament, and they are told with lyrical grace.

A former Catholic nun who worked for almost a decade in South America, O'Shea's own story is as compelling as those of the women she interviewed. Ana, a woman from Cuba, tells O'Shea, "When I was twelve I wanted to be a nun, but mother reminded me that I was impure because I had been raped, and to be a nun you had to be pure" (p. 61). O'Shea follows with her own story of entering a convent as a teenager: "I had the exhilarating feeling of belonging to something truly amazing. It may have had a lot to do with the uniform, or because we were fifty-four strong, healthy high school girls 
who had left our homes to give our lives to God" (pp. 61-62). When she describes the convent she is also describing the prison: the imposed silence, rules, discipline, rigid routine, isolation, deprivation, and punishment for such offences as touching one another or forming "particular friendships." The irony is clear: to devote one's self to God or to commit murder results in the same scenario, starting with separation from other human beings.

O'Shea doesn't hold herself apart from the women she interviewed. She opens up her own vulnerabilities and the worst of her own life experience as a tool for making sense rather than evoking pity. She doesn't evangelize but she implicitly believes in redemption. Women who were not formerly religious often acquire faith while awaiting death. We hear the familiar grief of victims of sexual abuse, and the unfamiliar suffering of being on death row when one's mother or grandmother is dying, when one's children are in crisis, or when a friend from the cell block is executed; and we learn what it is to live with unrelenting guilt and no hope of restitution. A woman named Christina, who killed her two children while severely depressed, says "A lot of regret, that's what goes through my mind, day in, day out - God's punishing me.... I am very ashamed" (p. 100).

One of the issues discussed by the women includes their treatment by the press. As Ana says, "The press doesn't care about feelings. They are only interested in the sensational.... They don't care if a person is suffering.... They play with your pain and desperation. We are a story to them.... I don't want anyone playing with my pain" (p. 102). Another woman describes how her son learned that she had been sentenced to death when he read it in a newspaper at school. He was eight years old.

Women who will never be returning to their children, and women convicted of killing their children, speak with the same grief. Debra, in Arizona, states: "I was still in total denial as to what happened to my son.... I was suffering from severe depression, shock, and hour-long crying spells... It was the loss of my son ... that just overwhelmed me" (p. 103). Christina says: "Sometimes I can't think about them. It's like they're being ripped away from me all over again. Every day I wonder why this tragedy has happened... I cannot figure out what I am supposed to learn. What can be so valuable for me to learn that it had to cost the lives of two children?" And Robin says: "I sometimes speak about my children in the present tense. Although they've been gone for over five years, it's still difficult to talk about. Sometimes it feels like it just happened yesterday. The pain is so great" (p. 148). 
Indeterminate imprisonment can be as cruel as capital punishment, and in some prisons women held on death row for years, due to delays and appeals, suffer unrelenting degradations inflicted by staff. Kelley describes the "verbal abuse by staff ... who call us 'death row bitches.' 'Are you scared to die?' they say. Or, when I once asked an officer for a light, he said, 'They'll give you one last one before they fry you'" (p. 131). Another woman, Robin in Idaho, tells of how the guard will tauntingly hold onto her mail for hours before finally giving it to her, “even when he isn't busy. If I have a telephone call scheduled at seven, he won't let me make it until eight or nine. Not that the phone is busy-I'm the only one here. He will withhold my supplies and search my room more than once in a shift" (p. 146).

For most of this book, the women's voices are rich with the fact of still being alive. Despite their grief, anger, guilt, and fear, they speak of their loved ones as if they had a future with them. Thus it is startling, as the book draws to a closing, to read their raw acknowledgements of their impending deaths. Kelley asks O'Shea in a letter, "Please tell everyone that the one thing I'd like is to have 'Forever Young' played at my execution. I don't know if you know this song. It's by Rod Stewart." Andrea, a black woman in Florida, speaks of how she "began to hallucinate ... a noose hanging in front of me," after being taken to the site of her execution in a motorcade, only to receive a temporary reprieve and returned to her cell. As Ana reminds the reader, women on death row have to face premature death at the hands of the state, and they also have to struggle with the ordinary fears of mortality: "My sorrow and loneliness are huge. To be forgotten is the worst" (p. 133137).

Donetta, a black woman in Pennsylvania, describes her dilemma with a question: "Do I want to live another year in hell, or do I want to die to escape this living hell?" (p. 148). Debra describes having to undergo a mock execution, a rehearsal for her own death. "I had to sign papers about my last meal, witnesses I wanted present, how my remains would be disposed of. My veins were examined by a doctor, the chaplain stopped by for a visit, my room was searched every day, psychiatrists came around, and I was moved into an isolation cell where I could be watched continuously by a video camera" (p. 85). Most poignantly, Andrea describes losing her friend: "[E]ven though Judy said she was not afraid to die, I knew when they took her away that she was. I could see the fear in her eyes. They had so many chains and shackles on that poor woman - and she was frail and thin - that she couldn't 
walk and they had to wheelchair her out.... But I must say this, Judy died bravely and with dignity" (p. 152).

This book invokes profound spiritual and philosophical questions, and brings compassion to the frailty of the human condition. With an implicit gender analysis, this book will appeal to a general audience, people who are themselves imprisoned, and students of criminology, sociology, and women's studies. It speaks to the ways that all human life is connected, for better and for worse. In a touching epilogue, having shared with readers the twists and turns of her own degradations, Kathleen O'Shea quotes Sister Helen Prejean, the anti-death penalty activist: "I am better than my worst mistake." And O'Shea then says, "I realized in my first interview with a woman awaiting execution that our similarities were quite substantial, our differences somewhat circumstantial.... I can say without qualification that I know women on death row today who are much better human beings than I am" (pp. 154-156).

Karlene Faith is a professor in the School of Criminology at Simon Fraser University. She is a long-time prison activist whose experiences include work with prisoners, especially women, in California and Canada. 